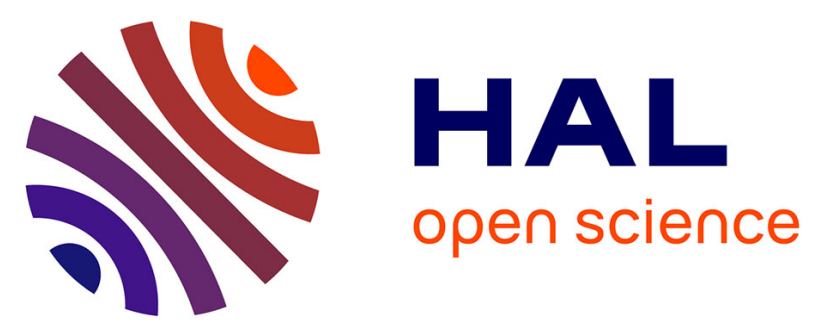

\title{
Dawson-type polyoxometalate nanoclusters confined in a carbon nanotube matrix as efficient redox mediators for enzymatic glucose biofuel cell anodes and glucose biosensors
}

Feriel Boussema, Andrew Gross, Fatma Hmida, Brahim Ayed, Hatem

Majdoub, Serge Cosnier, Abderrazak Maaref, Michael Holzinger

\section{To cite this version:}

Feriel Boussema, Andrew Gross, Fatma Hmida, Brahim Ayed, Hatem Majdoub, et al.. Dawson-type polyoxometalate nanoclusters confined in a carbon nanotube matrix as efficient redox mediators for enzymatic glucose biofuel cell anodes and glucose biosensors. Biosensors and Bioelectronics, 2018, 109, pp.20 - 26. 10.1016/j.bios.2018.02.060 . hal-01847126

\author{
HAL Id: hal-01847126 \\ https://hal.science/hal-01847126
}

Submitted on 19 Nov 2020

HAL is a multi-disciplinary open access archive for the deposit and dissemination of scientific research documents, whether they are published or not. The documents may come from teaching and research institutions in France or abroad, or from public or private research centers.
L'archive ouverte pluridisciplinaire HAL, est destinée au dépôt et à la diffusion de documents scientifiques de niveau recherche, publiés ou non, émanant des établissements d'enseignement et de recherche français ou étrangers, des laboratoires publics ou privés. 


\section{Dawson-type polyoxometalate nanoclusters confined in a carbon nanotube matrix as efficient redox mediators for enzymatic glu- cose biofuel cell anodes and glucose biosensors}

Feriel Boussema ${ }^{b}$, Andrew J. Gross ${ }^{a, d}$, Fatma Hmida $^{c}$, Brahim Ayed ${ }^{c}$, Hatem Majdoub ${ }^{b}$, Serge Cosnier ${ }^{a}$, Abderrazak Maaref ${ }^{b}$, and Michael Holzinger ${ }^{a}$

a Département de Chimie Moléculaire, CNRS-Univ. of Grenoble Alpes, 38041, France

e-mail : michael.holzinger@univ-grenoble-alpes.fr; phone : +33 456520811

b Laboratoire des Interfaces et des Matériaux Avancés, Faculté des Sciences de Monastir, Univ. Monastir, 5000, Tunisia

c Laboratoire de Matériaux et Cristallochimie, Faculté des Sciences de Monastir, Univ. Monastir, 5000, Tunisia

d CERMAV, CNRS Grenoble, 38041, France

Abstract: Two new inorganic-organic hybrid materials based on heteropolyoxometalates (POMs) : $\left(\mathrm{C}_{4} \mathrm{H}_{10} \mathrm{~N}\right)_{6}\left[\mathrm{P}_{2} \mathrm{Mo}_{18} \mathrm{O}_{62}\right]$. $4 \mathrm{H}_{2} \mathrm{O}\left(\mathrm{P}_{2} \mathrm{Mo}_{18}\right)$ and $\left(\mathrm{C}_{6} \mathrm{H}_{8} \mathrm{NO}\right)_{4}\left[\mathrm{H}_{2} \mathrm{P}_{2} \mathrm{~W}_{18} \mathrm{O}_{62}\right] \cdot 6 \mathrm{H}_{2} \mathrm{O}\left(\mathrm{P}_{2} \mathrm{~W}_{18}\right)$ are reported as mediators for electron transfer between FAD-dependent glucose dehydrogenase (FAD-GDH) and a multiwalled carbon nanotube (MWCNT) matrix for glucose biofuel cell and biosensor applications. These polyoxometalates were chosen due to their promising redox behavior in a potential range for mediated electron transfer with the glucose oxidizing enzyme, FAD-GDH. $\mathrm{P}_{2} \mathrm{Mo}_{18}$ and $\mathrm{P}_{2} \mathrm{~W}_{18}$ were immobilized on 1-pyrenemethylamine (PMA) functionalized MWCNT deposits. After immobilization of FAD-GDH, the $\mathrm{P}_{2} \mathrm{~W}_{18}$-modified MWCNT electrode demonstrated mediated electron transfer and provided a catalytic current density of $0.34 \mathrm{mAcm}^{-2}$ at $0.2 \mathrm{~V}$ vs SCE with an open circuit potential (OCP) of $-0.08 \mathrm{~V}$ vs SCE. A 10-fold increase in catalytic current to $4.7 \mathrm{mAcm}^{-2}$ at $0.2 \mathrm{~V}$ vs SCE and a slightly lower OCP of -0.10 $\mathrm{V}$ vs SCE was observed for an equivalent electrode modified with $\mathrm{P}_{2} \mathrm{Mo}_{18}$. The apparent superiority of $\mathrm{P}_{2} \mathrm{Mo}_{18}$ is related, at least in part, to its improved incorporation in the MWCNT matrix compared to $\mathrm{P}_{2} \mathrm{~W}_{18}$. Both POM-modified bioanodes showed exceptional stabilities with $45 \%$ of their initial performances remaining after 15 days. The mediated electron transfer capacities of the POMs were also evaluated in a glucose sensor setup and showed very satisfying performances for glucose detection, including a sensitivity of $0.198 \mathrm{mAmolL}^{-1} \mathrm{~cm}^{-2}$, a satisfying linear range between $1 \mathrm{mmolL}^{-1}$ and $20 \mathrm{mmolL}^{-1}$, and good reproducibility for the $\mathrm{P}_{2} \mathrm{Mo}_{18}$ electrode.

Keywords: Electron transfer mediator, Dawson type polyoxometalates, glucose biofuel cells, glucose dehydrogenase, multi walled carbon nanotubes 


\section{Introduction.}

The possibility of exchanging electrons between immobilized redox enzymes and electrodes clearly improves the efficiency of biosensors and is essential for biofuel cell applications (Saboe et al. 2017). Achieving efficient electron transfer with glucose oxidizing enzymes with flavin adenine dinucleotide (FAD) cofactors is a particular challenge since this redox unit is covered by a thick protein shell that makes direct electron transfer difficult, if not impossible. One of the key issues is that electron transfer is exponentially dependent on the distance between the redox active center and the electrode material (Marcus and Sutin 1985). One of the most common enzymes for glucose oxidation is glucose oxidase (GOx). Its FAD unit is protected by a glycosylated protein shell (total mass $\sim 160 \mathrm{kDa}$ ) which is responsible for its outstanding stabilities and activity over several pH values (Wilson and Turner 1992). However, the fact that GOx produces hydrogen peroxide via oxygen reduction, after glucose oxidation, is on the one hand a positive aspect for electrochemical biosensing (Ferri et al. 2011), but on the other hand, a drawback for biofuel cell anodes. Therefore, FAD-dependent glucose dehydrogenases (FAD-GDHs) are becoming prominent alternatives for the bioelectrocatalytic oxidation of glucose since they exhibit similar activity to GOx, whilst also benefiting from being insensitive to oxygen which avoids detrimental hydrogen peroxide production (Zafar et al. 2012).

For the wiring of FAD-dependent enzymes, the mediated electron transfer (MET) strategy, which uses a redox active compound of appropriate potential, is essential for many types of glucose biosensors and biofuel cells (Zhao et al. 2015). MET-based glucose biosensors can operate at convenient redox potentials without affecting the enzyme's activity (Saleem et al. 2015). Ferrocene and ferricyanide derivatives are commonly used mediators in glucose biosensor setups (Wang 2002) but they are inappropriate as anodic mediators in glucose biofuel cells since the glucose oxidation overpotential is much too high to achieve reasonable fuel cell potentials. For the bioconversion of energy, the development of redox mediators with potentials close to the enzyme's cofactor (here, FAD), and which exhibit fast electron transfer kinetics, 
still remains of high interest. Historically, the Heller group first described MET with GOx using an osmium-based redox polymer (Gregg and Heller 1991). Since the redox potential of osmium complexes can be adjusted by altering the ligand structure, more appropriate osmium-based redox hydrogels have been synthesized for glucose biofuel cell applications (Heller 1992; Mano et al. 2002; Pinyou et al. 2016). More recently, quinones have emerged as prominent alternatives to metal organic complexes due to efficient electron transfer kinetics and the possibility to improve operational lifetimes (Gross et al. 2017; Milton et al. 2015; Reuillard et al. 2015).

Another class of compounds with tunable redox potentials are polyoxometalates (POMs). POMs belong to a large family of inorganic nanoclusters which comprise of a metal-oxygen framework and have attracted interest in many fields such as catalysis (Wang et al. 2015) and electrocatalysis (Freire et al. 2016; Hamidi et al. 2008). POMs are attractive as they can be rationally designed to give a wide range of complex materials with tailored catalytic, electronic, and structural properties (Long et al. 2007; Miras et al. 2012; Zhou et al. 2007). POMs can also provide rich electrochemical processes with reversible multi-step and multi-electron transfers (Ueda 2015). The various electrocatalytic properties of POMs may be envisioned for energy conversion (Ji et al. 2015) or molecular sensing (Freire et al. 2016). For biomedical applications, POM composites and alloys have shown promising performances for the electrochemical detection of biomolecules such as ascorbic acid (vitamin c), dopamine (Zhou et al. 2013) (Zhang et al. 2014) and NADH, the reduced form of the coenzyme nicotinamide adenine dinucleotide (Ammam and Easton 2013). The first use of POMs with enzymes for glucose sensing was described by Turdean et al. (Turdean et al. 2002). A composite graphite electrode was prepared via electropolymerization of 1,8diaminonaphthalene in the presence of a trilacunary Keggin type POM, $\mathrm{Na}_{6} \mathrm{H}_{2} \mathrm{O}\left(\mathrm{Fe}_{4}\left[\mathrm{H}_{4} \mathrm{Fe}_{4}\left(\mathrm{PMo}_{9} \mathrm{O}_{34}\right)_{2}\left(\mathrm{H}_{2} \mathrm{O}\right)_{2}\right] \cdot \mathrm{H}_{2} \mathrm{O}\right.$. The electrode was modified with a biocatalytic layer comprising glutaraldehyde crosslinked GOx / BSA (bovine serum albumin). The POM electrode demonstrated efficient electrocatalytic reduction of enzymatically produced hydrogen peroxide at $-0.04 \mathrm{~V}$ (vs. $\mathrm{Ag} / \mathrm{AgCl}$. $\mathrm{KCl}_{\text {sat }}$ ) and showed very satisfying long term stability. More recently, Sahraoui et al. (Sahraoui et al. 
2016) described the use of a alpha-metatungstate POM cluster, $\mathrm{H}_{2} \mathrm{~W}_{12} \mathrm{O}_{40}{ }^{6-}$, as an electrocatalyst for the

reduction of hydrogen peroxide, produced by GOx. A good correlation between the glucose concentration and cathodic current density at $-0.8 \mathrm{~V}$ vs SCE was observed. Very importantly, in in these examples, the redox activity of the POM clusters was used simply as an electrocatalysis and not exploited for electron transfer between the electrode and the enzyme (i.e. for bioelectrocatalysis).

We want to introduce here, for the first time, two organic-inorganic POM materials $\left(\left(\mathrm{C}_{4} \mathrm{H}_{10} \mathrm{~N}\right)_{6}\left[\mathrm{P}_{2} \mathrm{Mo}_{18} \mathrm{O}_{62}\right] \cdot 4 \mathrm{H}_{2} \mathrm{O}\left(\mathrm{P}_{2} \mathrm{Mo} 18\right)\right.$ and $\left.\left(\mathrm{C}_{6} \mathrm{H}_{8} \mathrm{NO}\right)_{4}\left[\mathrm{H}_{2} \mathrm{P}_{2} \mathrm{~W}_{18} \mathrm{O}_{62}\right] \cdot 6 \mathrm{H}_{2} \mathrm{O}\right)\left(\mathrm{P}_{2} \mathrm{~W}_{18}\right)$ for efficient electron transfer between FAD-GDH and a pyrenemethylamine (PMA) functionalized multiwalled carbon nanotube (PMA/MWCNT) electrode. The POM cluster polyanions, with charge compensating organic cations, were investigated as an efficient assembly with MWCNT electrodes for improved stability at neutral $\mathrm{pH}$ and as potential electron relays for MET-based glucose biosensors and biofuel cell anodes.

\section{Experimental}

\subsection{Reagents and apparatus}

1-Pyrenemethylamine hydrochloride (PMA,95\%), D-glucose ( $\geq 99.5 \%)$, citric acid, monosodium phosphate monohydrate $\left(\mathrm{NaH}_{2} \mathrm{PO}_{4}, \geq 98 \%\right)$, disodium hydrogen phosphate heptahydrate $\left(\mathrm{Na}_{2} \mathrm{HPO}_{4}, 98-\right.$ 102\%), N,N-dimethylformamide (DMF, 99.9\%), $N$-Methyl-2-pyrrolidone (NMP), $\mathrm{Na}_{2} \mathrm{MoO}_{4}, \mathrm{Na}_{2} \mathrm{WO}_{4}$. $2 \mathrm{H}_{2} \mathrm{O}$, and 2-hydroxy-6-methylpyridine were purchased from Sigma-Aldrich. Flavin adenine dinucleotide-dependent glucose dehydrogenase (FAD-GDH, $1150 \mathrm{U} \mathrm{mg}^{-1}$ solid) was obtained from Sekisui Diagnostics (UK). Multi-walled carbon nanotubes (MWCNTs, $9.5 \mathrm{~nm}$ diameter, $1.5 \mu \mathrm{m}$ length, purity $>95 \%$ ), obtained from Nanocyl, were used as received without any purification step. Distilled water was obtained by water purification to a resistivity of $15 \mathrm{M} \Omega \mathrm{cm}$ using a Millipore Ultrapure system. Glucose solutions were left to mutarotate overnight to $\beta$-D-glucose prior to use.

Electrochemical measurements were performed in an electrochemical cell with a conventional three-electrode configuration using an Autolab pgstat100 potentiostat with Nova 2.0 software. A GCE working 
electrode was used together with a platinum wire counter electrode, and a saturated calomel reference electrode (SCE). Before each experiment, the surface of the glassy carbon electrode (GCE, 3 mm diameter) was polished with $2 \mu \mathrm{m}$ diameter diamond paste (MECAPREX Press PM) then rinsed with distilled water to remove any residual paste. Finally, the electrodes were sonicated for $5 \mathrm{~min}$ in ethanol and $5 \mathrm{~min}$ in acetone, followed by a thorough washing step with distilled water and ethanol. IR spectra were recorded using a Nicolet 470FT-IR spectrophotometer with pressed $\mathrm{KBr}$ pellets. SEM images were recorded using a FEI QUANTA-FEG 250 microscope with an Everhardt Thornley SED (secondary electron detector), an accelerating voltage of $3 \mathrm{kV}$, and a working distance of $8.0 \mathrm{~mm}$.

\subsection{Synthesis of $\left(\mathrm{C}_{4} \mathrm{H}_{10} \mathrm{~N}\right)_{6}\left(\mathrm{P}_{2} \mathrm{Mo18}_{62} \mathrm{O}_{62} \cdot \mathrm{H}_{2} \mathrm{O}\right.$}

The POM $\left(\mathrm{C}_{4} \mathrm{H}_{10} \mathrm{~N}\right)_{6}\left(\mathrm{P}_{2} \mathrm{Mo}_{18} \mathrm{O}_{62}\right) \cdot 4 \mathrm{H}_{2} \mathrm{O}$, was synthesized as described in our recent work (Hmida et al. 2015). Briefly $\mathrm{Na}_{2} \mathrm{MoO}_{4} \cdot 2 \mathrm{H}_{2} \mathrm{O}(1 \mathrm{~g}, 4 \mathrm{mmol})$ was dissolved in water $(25 \mathrm{~mL})$ with stirring. $\mathrm{H}_{3} \mathrm{PO}_{4}(0.5$ $\mathrm{mL}, 0.2 \mathrm{mmol})$ and pyrrolidine $(0.2 \mathrm{mmol})$ were then added to the mixture (a light turbidity occurred which was allowed to clear with time before the next drop was added) and the $\mathrm{pH}$ was adjusted to about 2.5-2.6 by adding $6 \mathrm{mmolL}^{-1} \mathrm{HCl}$. The mixture was refluxed at $353 \mathrm{~K}$ for $3 \mathrm{~h}$ and then cooled to room temperature. Slow evaporation of the solvent at room temperature led to green prismatic crystals. $\left(\mathrm{C}_{4} \mathrm{H}_{10} \mathrm{~N}\right)_{6}\left(\mathrm{P}_{2} \mathrm{Mo}_{18} \mathrm{O}_{62}\right) \cdot 4 \mathrm{H}_{2} \mathrm{O}$ was characterized by single crystal X-ray analysis and IR spectroscopy (see supplementary material).

\subsection{Synthesis of $\left(\mathrm{C}_{6} \mathrm{H}_{8} \mathrm{NO}\right)_{4}\left(\mathrm{P}_{2} \mathrm{~W}_{18} \mathrm{O}_{62}\right) \cdot 6 \mathrm{H}_{2} \mathrm{O}$}

$\left(\mathrm{C}_{6} \mathrm{H}_{8} \mathrm{NO}\right)_{4}\left[\mathrm{H}_{2} \mathrm{P}_{2} \mathrm{~W}_{18} \mathrm{O}_{62}\right] 6 \mathrm{H}_{2} \mathrm{O}$, was synthesized by dissolving $\mathrm{Na}_{2} \mathrm{WO}_{4} \cdot 2 \mathrm{H}_{2} \mathrm{O}(0.33 \mathrm{~g}, 1 \mathrm{mmol})$ in 10 $\mathrm{mL}$ of water. The solution was heated at $80{ }^{\circ} \mathrm{C}$ for $45 \mathrm{~min}$ and the $\mathrm{pH}$ was adjusted to 4.5 with aqueous $\mathrm{HCl}\left(5 \mathrm{mmolL}^{-1}\right)$ after $0.3 \mathrm{ml}$ of $\mathrm{H}_{3} \mathrm{PO}_{4}$ was added. Then, a solution of 2-hydroxy-6-methylpyridine $(0.5$ $\mathrm{g}, 6 \mathrm{mmol})$ in water $(10 \mathrm{~mL})$ was added dropwise (correspondingly, when the solution cleared, the next drop was added). The final $\mathrm{pH}$ was adjusted to 4.5 by addition of diluted $\mathrm{HCl}\left(5 \mathrm{mmolL}^{-1}\right)$. The mixture 
was transformed to a Teflon-lined stainless steel autoclave $(18 \mathrm{~mL})$ and kept at $140{ }^{\circ} \mathrm{C}$ for five days. After the autoclave had cooled down to room temperature, yellow block crystals were filtered off and washed with distilled water. This compound was characterized by single crystal X-ray analysis, UV-Vis, and IR spectroscopy (see supplementary material).

\subsection{Preparation of the bioelectrodes}

The MWCNT-based electrodes were prepared in several steps. First, MWCNTs were dispersed in NMP by $30 \mathrm{~min}$ sonication of $5 \mathrm{mg}$ of nanotubes in $1 \mathrm{~mL}$ of NMP until a homogenous black suspension was obtained. Then, the solution was drop-casted on glassy carbon electrodes to obtain a MWCNT film on the electrode. The MWCNT electrodes were functionalized with PMA via incubation in a 1-pyrenemethylamine hydrochloride ( $1 \mathrm{mg} \mathrm{mL}^{-1}$ in DMF) solution for $\left.60 \mathrm{~min}\right)$. The solvents were removed under vacuum and the electrodes were then washed with McIlvaine buffer. The functionalized electrodes were then incubated in a $10^{-4}$ molL ${ }^{-1}$ solution of $\mathrm{P}_{2} \mathrm{~W}_{18}$ or $\mathrm{P}_{2} \mathrm{Mo}_{18}$ in $\mathrm{H}_{2} \mathrm{SO}_{4}\left(1 \mathrm{molL}^{-1}\right)$. After intensive rinsing to remove the acid, the electrodes were finally incubated in a $5 \mathrm{mg} \mathrm{mL}^{-1}$ solution of FAD-GDH in McIlvaine buffer overnight. The electrodes were dried under vacuum, washed with McIlvaine buffer, and stored at $4^{\circ} \mathrm{C}$ until further use.
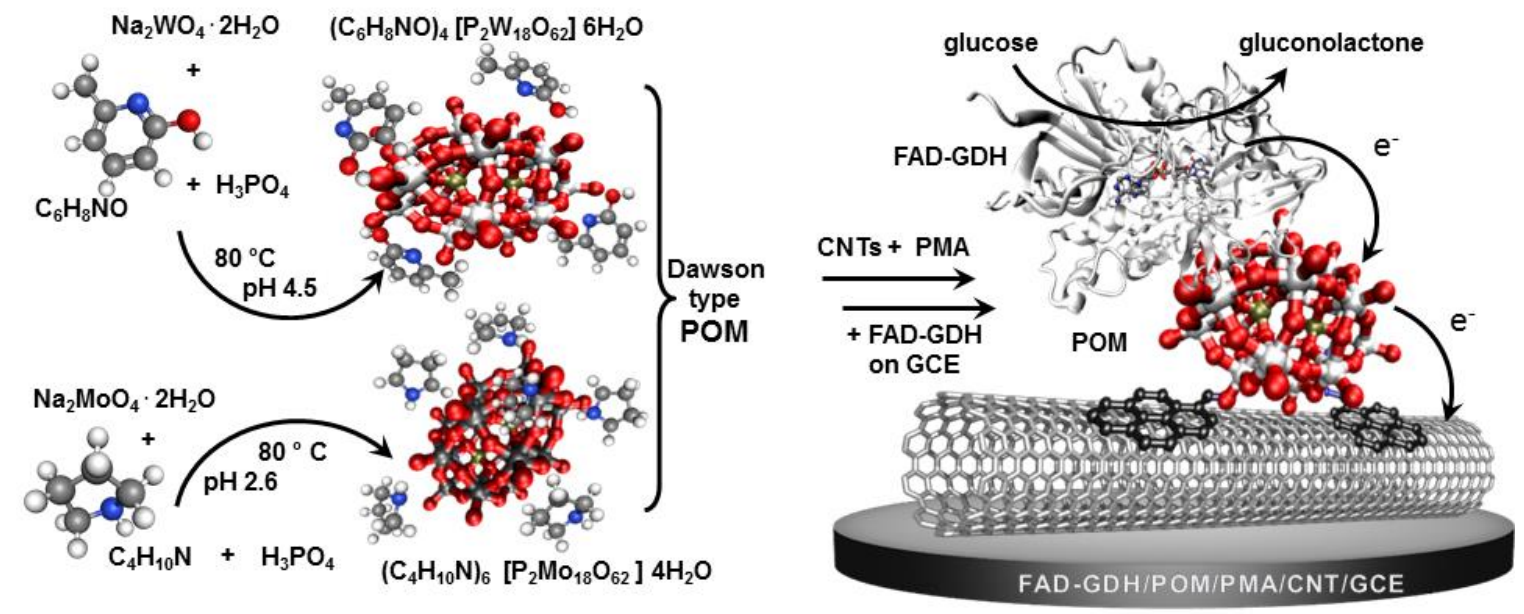

Scheme 1: Compounds and conditions for the synthesis of the Dawson type POMs $\left(\left(\mathrm{C}_{4} \mathrm{H}_{10} \mathrm{~N}\right)_{6}\right.$ $\left[\mathrm{P}_{2} \mathrm{Mo}_{18} \mathrm{O}_{62}\right] \cdot 4 \mathrm{H}_{2} \mathrm{O}$ and $\left.\left(\mathrm{C}_{6} \mathrm{H}_{8} \mathrm{NO}\right)_{4}\left[\mathrm{H}_{2} \mathrm{P}_{2} \mathrm{~W}_{18} \mathrm{O}_{62}\right] \cdot 6 \mathrm{H}_{2} \mathrm{O}\right)$ and their integration on a CNT bioelectrode for mediated electron transfer with FAD-GDH and bioelectrocatalytic glucose oxidation. 


\section{Results and discussion}

\subsection{Electrochemical behavior of $\mathbf{P}_{2} \mathrm{~W}_{18}$ - and $\mathbf{P}_{2}$ Mo18-modified electrodes}

The electrochemical behavior of the polyoxometalates, $\mathrm{P}_{2} \mathrm{~W}_{18}$ and $\mathrm{P}_{2} \mathrm{Mo}_{18}$, was first characterized in acidic solution $\left(10^{-4} \mathrm{molL}^{-1}, 0.1 \mathrm{molL}^{-1} \mathrm{H}_{2} \mathrm{SO}_{4}\right)$ using cyclic voltammetry (CV) with bare GCE as the working electrode. In Figure $1 \mathrm{~A}, \mathrm{P}_{2} \mathrm{~W}_{18}$ shows four reversible redox systems with a half-wave potential, $\mathrm{E}_{1 / 2}=0.04 \mathrm{~V},-0.12 \mathrm{~V},-0.39 \mathrm{~V}$, and $-0.64 \mathrm{~V}$ vs SCE, assigned to two one-electron and two two-electron reductions (Keita and Nadjo 1987; Wang et al. 2011) according to the equations:

$\mathrm{P}_{2} \mathrm{~W}_{18}{ }^{\mathrm{VI}} \mathrm{O}_{62}{ }^{6-}+\mathrm{e}^{-} \leftrightharpoons \mathrm{P}_{2} \mathrm{~W}_{17}{ }^{\mathrm{VI}} \mathrm{W}^{\mathrm{V}} \mathrm{O}_{62}{ }^{7-}$

$\mathrm{P}_{2} \mathrm{~W}_{17}{ }^{\mathrm{VI}} \mathrm{W}^{\mathrm{V}} \mathrm{O}_{62}{ }^{7-}+\mathrm{e}^{-} \leftrightharpoons \mathrm{P}_{2} \mathrm{~W}_{16}{ }^{\mathrm{VI}} \mathrm{W}^{\mathrm{V}} \mathrm{O}_{62}{ }^{8-}$

$\mathrm{P}_{2} \mathrm{~W}_{16}{ }^{\mathrm{VI}} \mathrm{W}_{2}{ }^{\mathrm{V}} \mathrm{O}_{62}{ }^{8-}+2 \mathrm{e}^{-}+2 \mathrm{H}^{+} \leftrightharpoons \mathrm{H}_{2} \mathrm{P}_{2} \mathrm{~W}_{14}{ }^{\mathrm{VI}} \mathrm{W}_{4}{ }^{\mathrm{V}} \mathrm{O}_{62}{ }^{8-}$

$\mathrm{H}_{2} \mathrm{P}_{2} \mathrm{~W}_{14}{ }^{\mathrm{VI}} \mathrm{W}_{4}{ }^{\mathrm{V}} \mathrm{O}_{62}{ }^{8-}+2 \mathrm{e}^{-}+2 \mathrm{H}^{+} \leftrightharpoons \mathrm{H}_{4} \mathrm{P}_{2} \mathrm{~W}_{12}{ }^{\mathrm{VI}} \mathrm{W}_{6}{ }^{\mathrm{V}} \mathrm{O}_{62}{ }^{8-}$

$\mathrm{P}_{2} \mathrm{Mo}_{18}$ shows three reversible redox systems at $\mathrm{E}_{1 / 2}=0.31 \mathrm{~V}, 0.18 \mathrm{~V}$, and $0.01 \mathrm{~V}$ vs $\mathrm{SCE}$, which correspond to three two-electron reductions, as previously described (Hmida et al. 2015; Zhou et al. 2007) (Figure 1B):

$$
\begin{aligned}
& \mathrm{P}_{2} \mathrm{Mo}_{18}{ }^{\mathrm{VI}} \mathrm{O}_{62}{ }^{6-}+2 \mathrm{e}^{-}+2 \mathrm{H}^{+} \leftrightharpoons \mathrm{H}_{2} \mathrm{P}_{2} \mathrm{Mo}_{16}{ }^{\mathrm{VI}} \mathrm{Mo}_{2}{ }^{\mathrm{V}} \mathrm{O}_{62}{ }^{6-} \\
& \mathrm{H}_{2} \mathrm{P}_{2} \mathrm{Mo}_{16}{ }^{\mathrm{VI}} \mathrm{Mo}_{2}{ }^{\mathrm{V}} \mathrm{O}_{62}{ }^{6-}+2 \mathrm{e}^{-}+2 \mathrm{H}^{+} \leftrightharpoons \mathrm{H}_{4} \mathrm{P}_{2} \mathrm{Mo}^{\mathrm{VI}}{ }_{14} \mathrm{Mo}_{4}{ }^{\mathrm{V}} \mathrm{O}_{62}{ }^{6-} \\
& \mathrm{H}_{4} \mathrm{P}_{2} \mathrm{Mo}_{14}{ }^{\mathrm{VI}} \mathrm{Mo}_{4}{ }^{\mathrm{V}} \mathrm{O}_{62}{ }^{6-}+2 \mathrm{e}^{-}+2 \mathrm{H}^{+} \leftrightharpoons \mathrm{H}_{6} \mathrm{P}_{2} \mathrm{Mo}_{12}{ }^{\mathrm{VI}} \mathrm{Mo}_{6}{ }^{\mathrm{V}} \mathrm{O}_{62}{ }^{6-}
\end{aligned}
$$


With the aim to study the polyoxometalates for mediated electron transfer with FAD-GDH, we studied their electrochemical behavior in McIlvaine buffer at pH 7.0 after confinement in a MWCNT matrix. In the potential range of $0.2 \mathrm{~V}$ and $-0.8 \mathrm{~V}$ vs SCE, $\mathrm{P}_{2} \mathrm{~W}_{18}$ shows four reversible redox systems at $\mathrm{E}_{1 / 2}=-0.04$ $\mathrm{V},-0.20 \mathrm{~V},-0.57 \mathrm{~V}$, and $-0.67 \mathrm{~V}$ (Figure 1C) according to equations (1) to (4). The first two electron reductions are almost independent of $\mathrm{pH}$ (Sadakane and Steckhan 1998) and are slightly shifted to negative values compared to the voltammograms recorded in acidic solution. Both redox systems are situated in the potential range of interest for mediated electron transfer with FAD-GDH. The redox system III/III', related to equation (3), is the most affected by the $\mathrm{pH}$ change and exhibited a $180 \mathrm{mV}$ shift to lower potentials. In spite of the $\mathrm{pH}$ dependent redox process shown in equation (4), the $\mathrm{E}_{1 / 2}$ value corresponding to the IV/IV' peaks is less affected by the $\mathrm{pH}$ change (Ammam 2013).

Since the electrochemical reductions of $\mathrm{P}_{2} \mathrm{Mo}_{18}$ are two-electron two-proton processes, the increased $\mathrm{pH}$ from $\mathrm{pH} 1.0$ to $\mathrm{pH} 7.0$ led to a clear negative shift of the reversible redox waves, as shown in Figure 1D compared to Figure 1C (Ammam and Easton 2011). The two systems corresponding to equations (5) and (6), situated at $E_{1 / 2}=-0.04 \mathrm{~V}$ and $-0.22 \mathrm{~V}$, shifted perfectly into the potential range of interest. The third two-electron redox couple (equation (7)) could not be resolved for the $\mathrm{P}_{2} \mathrm{Mo}_{18}$-modified electrode even after extending the potential window, consistent with instability and irreversibility for this process (not shown). It should be noted that the PMA-functionalized MWCNT deposits provide an efficient platform for the immobilization of the two polyoxometalate compounds. By potential cycling at different scan rates, a linear dependency of the peak current versus the scan rate was observed for both types of POMmodified electrodes, confirming that the electroactive POMs are surface bound (supplementary material: Figure S6 and S7). Without PMA modification of the MWCNTs, no signals related to the POMs were resolved (not shown).

The surface coverage $(\Gamma)$ of electroactive $\mathrm{P}_{2} \mathrm{~W}_{18}$ or $\mathrm{P}_{2} \mathrm{Mo}_{18}$ clusters at the surface of GCE was determined by integration of the charge under the polyoxometalate reduction peaks after subtracting the capacitive current of the MWCNTs, according to Laviron's equation: 
where $\mathrm{n}$ is the number of electrons involved in the redox process, $\mathrm{F}$ is the Faraday's constant, $\mathrm{A}$ is the geometric surface area of the electrode $\left(0.071 \mathrm{~cm}^{2}\right), \mathrm{R}$ is the gas constant, $\mathrm{T}$ is the temperature, and $v$ is the scan rate. The average surface coverage of $\mathrm{P}_{2} \mathrm{~W}_{18}$ was $1.6 \times 10^{-9} \mathrm{~mol} \mathrm{~cm}^{-2}$ while that of $\mathrm{P}_{2} \mathrm{Mo}_{18}$ was $1.2 \times 10^{-8} \mathrm{~mol} \mathrm{~cm}^{-2}$ based on voltammograms recorded at $5 \mathrm{mV} \mathrm{s}^{-1}$.
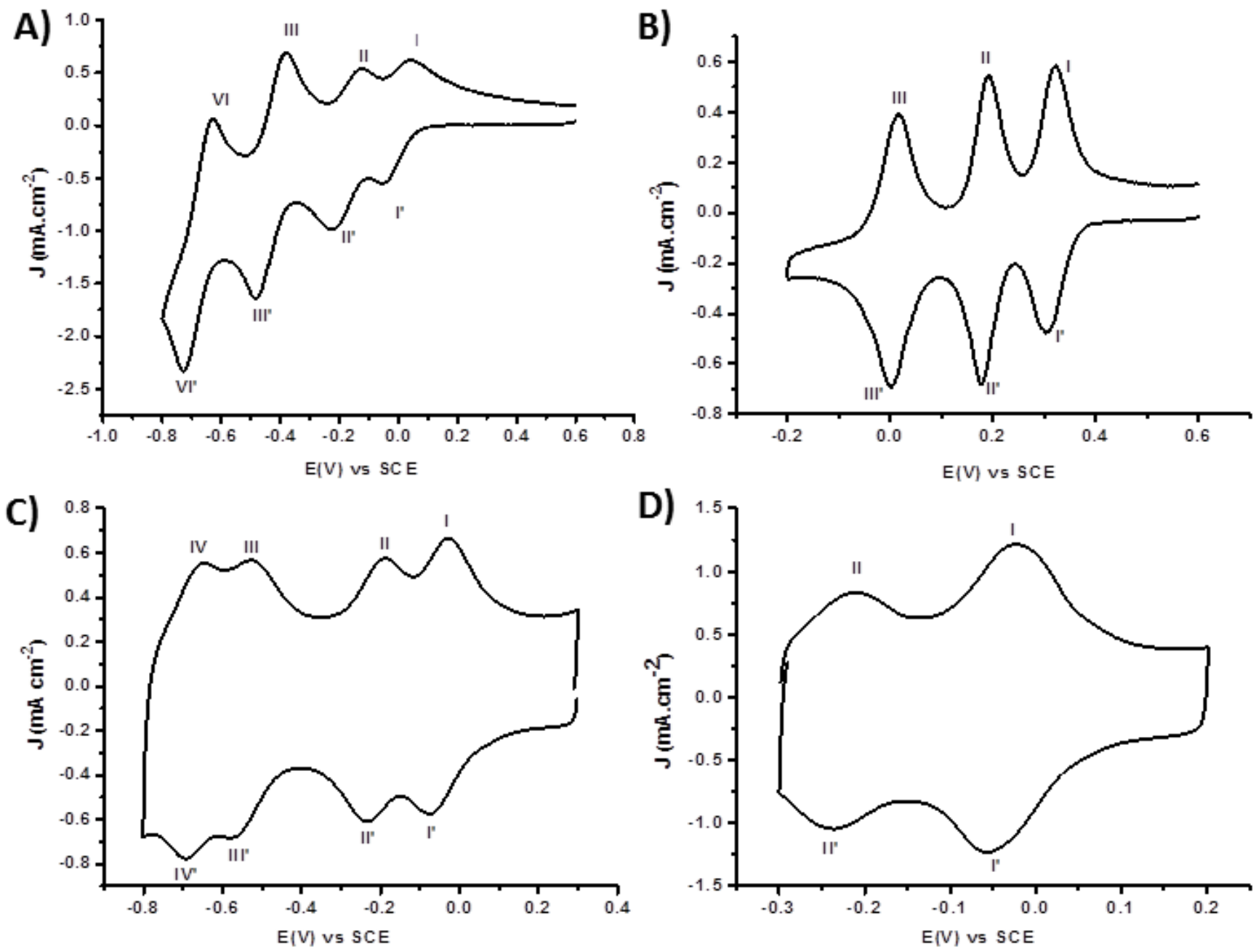

Figure 1. CV scans of (A) $\mathrm{P}_{2} \mathrm{~W}_{18}$ and (B) $\mathrm{P}_{2} \mathrm{Mo}_{18}$ in acidic aqueous solution $\left(10^{-4}\right.$ mol.L $\mathrm{L}^{-1}, 0.1 \mathrm{molL}^{-1}$ $\mathrm{H}_{2} \mathrm{SO}_{4}$ ) at bare GCE. Scan rate: $100 \mathrm{mV} \mathrm{s}^{-1}$. CV scans of (C) $\mathrm{P}_{2} \mathrm{~W}_{18} / \mathrm{PMA} / \mathrm{MWCNTs}$ and (D) $\mathrm{P}_{2} \mathrm{Mo}_{18} / \mathrm{PMA} / \mathrm{MWCNTs}$ in McIlvaine buffer at $\mathrm{pH}$ 7.0. Scan rate: $10 \mathrm{mV} \mathrm{s}^{-1}$. 


\subsection{Morphological studies of $\mathbf{P}_{2} M o 18 / P M A / M W C N T s$ and $P_{2} W_{18} / P M A / M W C N T s$ deposits}

To gain more insight into the observed electrochemical behavior of the $\mathrm{P}_{2} \mathrm{Mo}_{18} / \mathrm{PMA} / \mathrm{MWCNTs}$ and $\mathrm{P}_{2} \mathrm{~W}_{18} / \mathrm{PMA} / \mathrm{MWCNTs}$ electrodes, and, in particular, the difference of surface coverage by almost a factor of 10, we performed morphological studies using scanning electron microscopy (SEM). Figure 2 shows representative SEM images of PMA/MWCNTs deposits before and after modification with the POMs.

The SEM image of PMA-modified MWCNTs (Figure 2A) shows a typical porous morphology of entangled CNTs without traces of PMA residues. After deposition of $\mathrm{P}_{2} \mathrm{Mo}_{18}$, the deposit appears very undulated with small aggregates homogeneously incorporated in the MWCNT matrix, as seen in Figure 2B. It seems that the protonation of PMA in acidic media provokes a swelling of the MWCNT deposit which enables good penetration of $\mathrm{P}_{2} \mathrm{Mo}_{18}$ in the structure. After drying, small POM particles are formed with a homogenous distribution which indicates a good initial surface coverage of $\mathrm{P}_{2} \mathrm{Mo}_{18}$ on the PMA/MWCNTs substrate. For the $\mathrm{P}_{2} \mathrm{~W}_{18} / \mathrm{PMA} / \mathrm{MWCNTs}$ samples, a similar undulation is observed (Figure 2C) but fewer particles are observed and they are larger. Here, $\mathrm{P}_{2} \mathrm{~W}_{18}$ seems to interact much less with the PMA/MWCNTs matrix, even when the same swelling effect of the MWCNT structure is observed. It can be assumed that, under these preparation conditions, the formed 2-hydroxy-6-methylpyridinium ligand provokes electrostatic repulsion with the protonated PMA-MWCNT layer, thus leading to the formation of larger aggregates and less effective inclusion of $\mathrm{P}_{2} \mathrm{~W}_{18}$. This argument also explains the ten-fold lower surface coverage of electroactive $\mathrm{P}_{2} \mathrm{~W}_{18}$ revealed by the electrochemical studies.
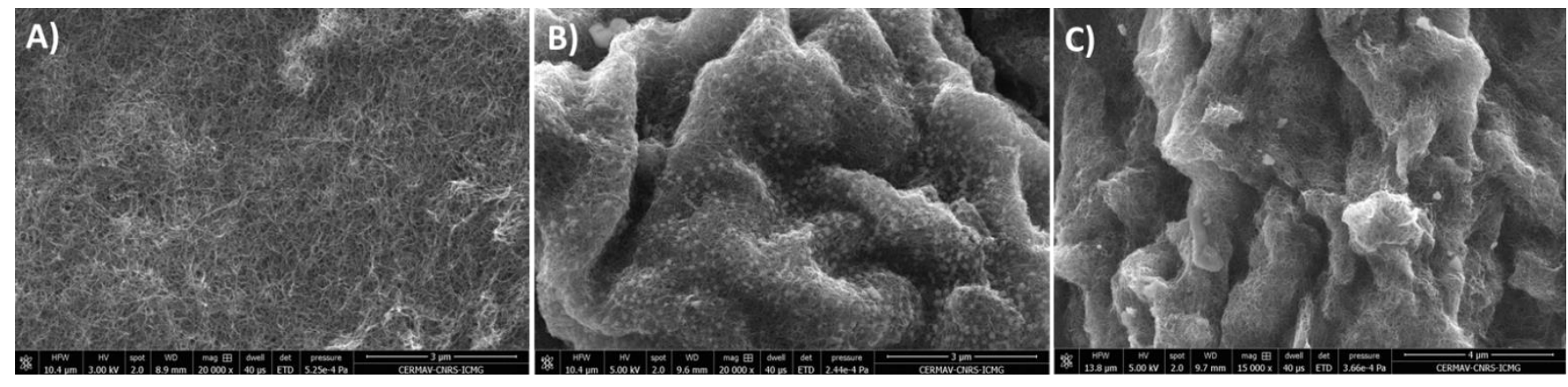

Figure 2: Representative SEM images of A) PMA/MWCNTs, B) $\mathrm{P}_{2} \mathrm{Mo}_{18} / \mathrm{PMA} / \mathrm{MWCNTs}$ and C) $\mathrm{P}_{2} \mathrm{~W}_{18} / \mathrm{PMA} / \mathrm{MWCNTs}$. 


\subsection{Mediated electron transfer between FAD-GDH and MWCNTs with $P_{2} W_{18}$ and $P_{2} M o 18$}

The anodic onset potentials of redox system (I) for both types of POM/PMA/MWCNTs composites are in the suitable range for electron mediation with FAD-dependent oxidizing enzymes. FAD-GDH was used to evaluate the wiring capacities of POMs after its immobilization on the electrodes by simple incubation in enzyme-containing Mcllvaine buffer solution overnight. To evaluate the bioelectrocatalytic glucose oxidation activity of the hybrid nanocluster-enzyme modified electrodes, the catalytic responses of the FAD-GDH/ $/ \mathrm{P}_{2} \mathrm{~W}_{18} / \mathrm{PMA} / \mathrm{MWCNTs}$ and FAD-GDH/ ${ }_{2} \mathrm{Mo}_{18} / \mathrm{PMA} / \mathrm{MWCNTs}$ electrodes were compared. The cyclic voltammograms of different modified electrodes were studied in Mcllvaine buffer at $\mathrm{pH} 7$ in the presence and absence of $100 \mathrm{mmol} \cdot \mathrm{L}^{-1}$ glucose at a scan rate of $5 \mathrm{mV} \mathrm{s}^{-1}$.

Figure 3A and 3B show an illustration of the bioelectrocatalytic oxidation of glucose to gluconolactone mediated by $\mathrm{P}_{2} \mathrm{~W}_{18}(\mathrm{~A})$ and $\mathrm{P}_{2} \mathrm{Mo}_{18}(\mathrm{~B})$ modified electrodes. In Figure $3 \mathrm{C}$ and $3 \mathrm{D}$, the cyclic voltammograms of FAD-GDH/ $\mathrm{P}_{2} \mathrm{~W}_{18} / \mathrm{PMA} / \mathrm{MWCNTs}$ (B) and FAD-GDH/P $\mathrm{P}_{2} \mathrm{Mo}_{18} / \mathrm{PMA} / \mathrm{MWCNTs}$ (D) electrodes clearly reveal catalytic current signals consistent with mediated electron transfer in the presence of 100 mmol. $\mathrm{L}^{-1}$ glucose. No catalytic current was measured in the absence of glucose. It is also noted that no catalytic current was observed at the FAD-GDH-modified electrode in the absence of POMs. 

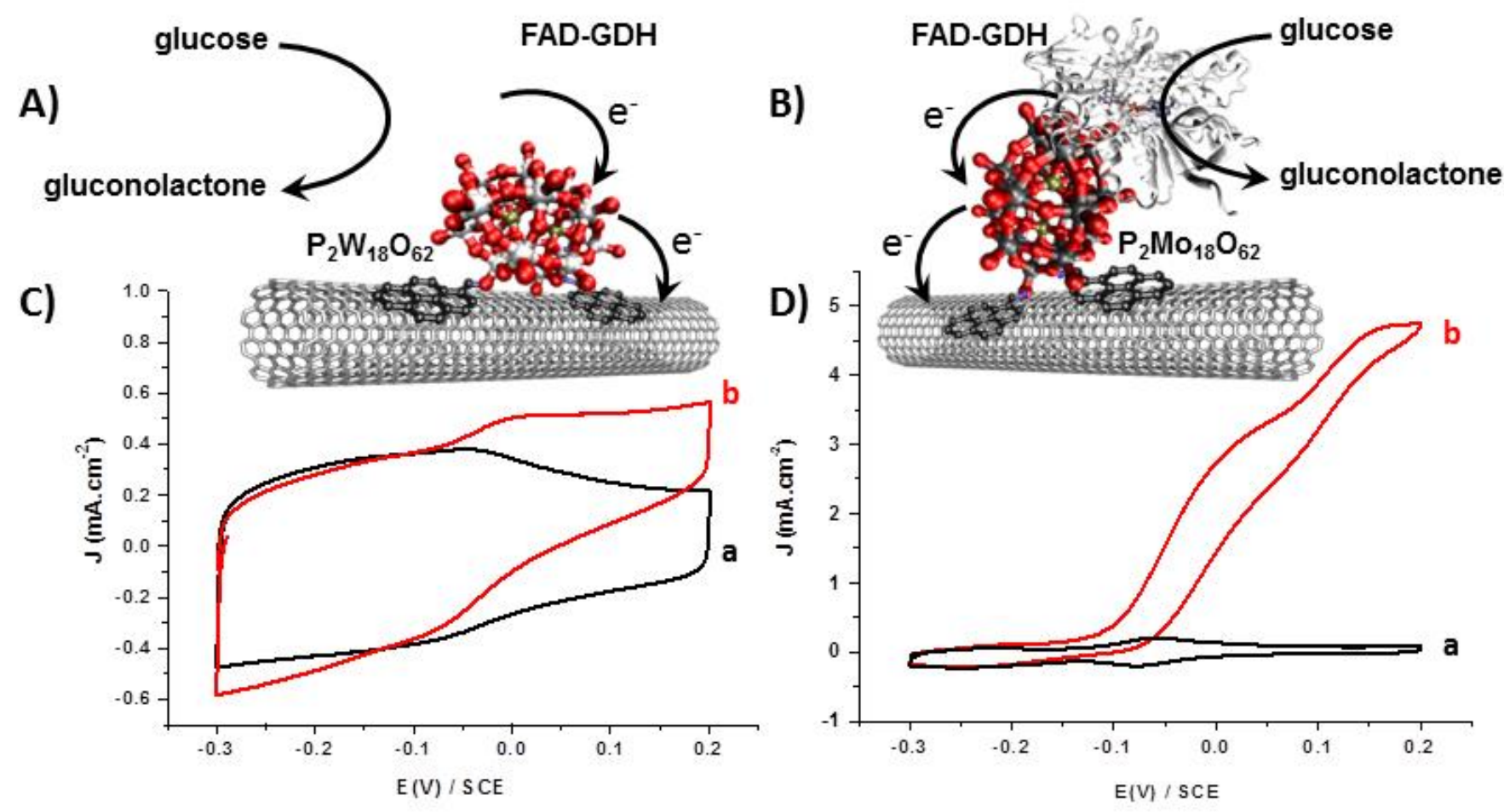

Figure 3: (A, B) Schematic presentation of the bioelectrocatalytic oxidation of glucose by FAD-GDH via mediated electron transfer with (A) $\mathrm{P}_{2} \mathrm{~W}_{18}$ - and (B) $\mathrm{P}_{2} \mathrm{Mo}_{18}$-modified MWCNT electrodes. (C, D) CV scans at FAD-GDH/ $\mathrm{P}_{2} \mathrm{~W}_{18} / \mathrm{PMA} / \mathrm{MWCNTs}$ and FAD-GDH/ ${ }_{2} \mathrm{Mo}_{18} / \mathrm{PMA} / \mathrm{MWCNTs}$ electrodes recorded (a) without and (b) in the presence of $100 \mathrm{mmol} . \mathrm{L}^{-1}$ glucose. Voltammograms were recorded in McIlvaine buffer at $\mathrm{pH} 7.0$ at a scan rate of $5 \mathrm{mV} . \mathrm{s}^{-1}$.

The mediated bioelectrocatalysis of $\mathrm{P}_{2} \mathrm{~W}_{18}$-modified electrodes shows an open circuit potential (OCP) at $-0.08 \mathrm{~V}$ vs SCE and a catalytic current density of $0.34 \mathrm{~mA} \mathrm{~cm}^{-2}$ at $0.2 \mathrm{~V}$. In contrast, the voltammograms recorded at $\mathrm{P}_{2} \mathrm{Mo}_{18}$-modified electrodes showed much higher current densities of $4.7 \mathrm{~mA} \mathrm{~cm}^{-2}$ at $0.2 \mathrm{~V}$, and an attractively lower OCP at $-0.1 \mathrm{~V}$ vs SCE. The higher performance for $\mathrm{P}_{2} \mathrm{Mo}_{18}$ in terms of both the onset potential and catalytic glucose oxidation current are most likely due to the improved stability and incorporation of $\mathrm{P}_{2} \mathrm{Mo}_{18}$ in the MWCNT matrix which resulted in higher amounts of immobilized POM. Figure 4A displays the bioelectrocatalytic behavior of FAD-GDH/ $\mathrm{P}_{2} \mathrm{~W}_{18} / \mathrm{PMA} / \mathrm{MWCNTs}$ and FAD$\mathrm{GDH} / \mathrm{P}_{2} \mathrm{Mo}_{18} / \mathrm{PMA} / \mathrm{MWCNTs}$ electrodes at increasing glucose concentrations. Increasing current densities were observed for both electrodes with increasing concentrations. At low glucose concentrations the 
$\mathrm{P}_{2} \mathrm{~W}_{18}$-modified electrode is clearly less performing than the electrode modified with $\mathrm{P}_{2} \mathrm{Mo}_{18}$. No further current increase was measured at glucose concentrations higher than $10 \mathrm{mmolL}^{-1}$ for the $\mathrm{P}_{2} \mathrm{~W}_{18}$ electrodes, which reached a maximum current density of $0.4 \mathrm{mAcm}^{-2}$. The comparatively low catalytic current at glucose saturation can again be attributed to the reduced amount of this POM on the MWCNT electrode. The maximum current density observed was reached at $4.5 \mathrm{mAcm}^{-2}$ with $\mathrm{P}_{2} \mathrm{Mo}_{18}$-modified electrodes at glucose concentrations higher than $50 \mathrm{mmolL}^{-1}$. Figure 4B shows the calibration curves, obtained from chronoamperometric measurements, which enabled the determination of the sensitivity, linear range and detection limit of the electrodes for glucose detection. The FAD-GDH/ ${ }_{2} \mathrm{Mo}_{18} / \mathrm{PMA} / \mathrm{MWCNT}$ electrodes exhibited the best glucose biosensor performance with the highest sensitivity of $0.198 \pm 0.015 \mathrm{mAcm}^{-2}$ $\mathrm{Lmmol}^{-1}$ and a larger linear range between $1 \mathrm{mmolL}^{-1}$ and $20 \mathrm{mmolL}^{-1}$ ). The biosensor based on FAD$\mathrm{GDH} / \mathrm{P}_{2} \mathrm{~W}_{18} / \mathrm{PMA} / \mathrm{MWCNT}$ electrodes exhibited significantly lower sensitivity of $0.034 \pm 0.008 \mathrm{mAcm}^{-}$ ${ }^{2} \mathrm{Lmmol}^{-1}$.
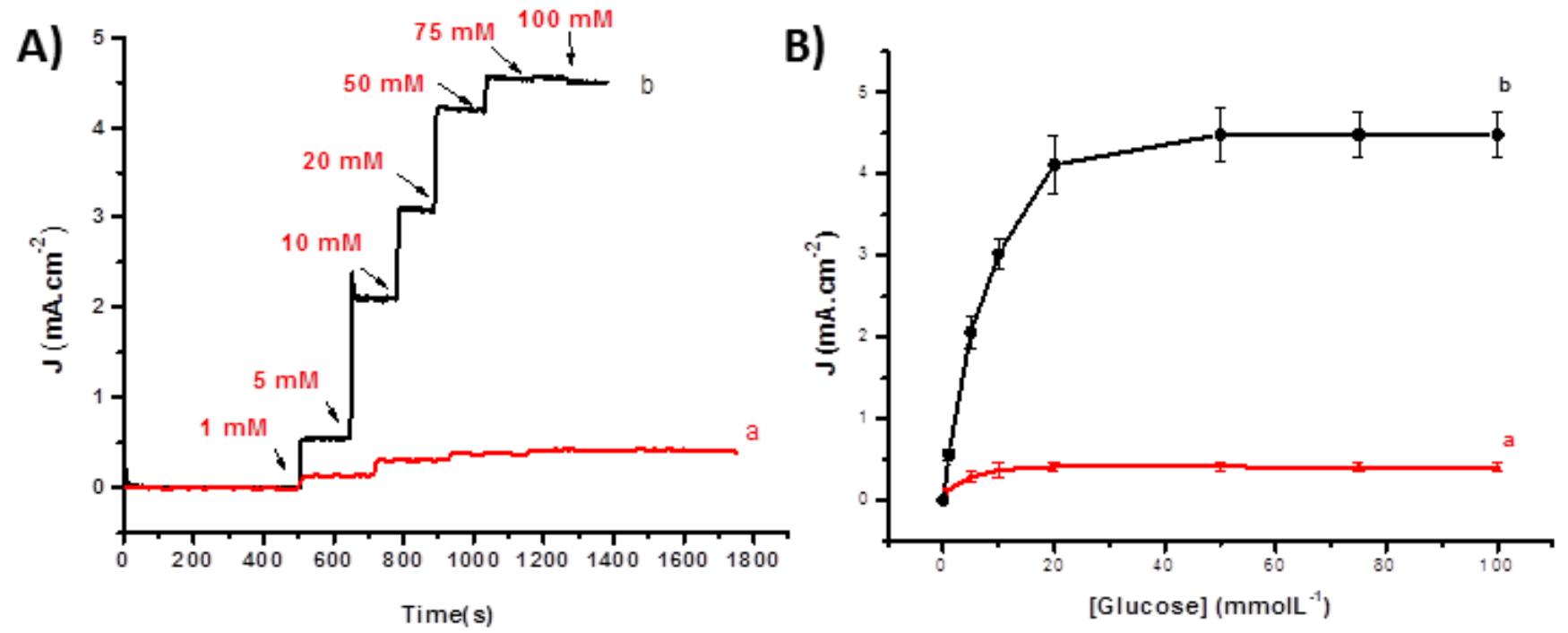

Figure 4: (A) Current density-time responses at increasing glucose concentrations for (a) FAD$\mathrm{GDH} / \mathrm{P}_{2} \mathrm{~W}_{18} / \mathrm{PMA} / \mathrm{MWCNTs}$ and (b) FAD-GDH/P $\mathrm{P}_{18} / \mathrm{PMA} / \mathrm{MWCNTs}$ electrodes (B) Catalytic current density evolution as a function of glucose concentration for (a) FAD-GDH/ $\mathrm{P}_{2} \mathrm{~W}_{18} / \mathrm{PMA}$ /MWCNTs and (b) FAD-GDH/ ${ }_{2} \mathrm{Mo}_{18} / \mathrm{PMA} / \mathrm{MWCNTs}$ electrodes. Chronoamperometric experiments were performed at a fixed potential of $0.2 \mathrm{~V}$ vs. SCE in McIlvaine buffer at pH 7.0. Catalytic currents in (B) were measured after 30 seconds discharge. 
The difference in catalytic glucose oxidation performance between the two POM composites corresponds approximately to the difference of the surface coverage. It can therefore be assumed that $\mathrm{P}_{2} \mathrm{~W}_{18}$ might have similar enzyme wiring capacities as $\mathrm{P}_{2} \mathrm{Mo}_{18}$. However, several attempts were made to adjust the surface coverage of $\mathrm{P}_{2} \mathrm{~W}_{18}$, but unfortunately, this was without conclusive results.

\subsection{Stability tests}

The operational stability is one of the key parameters of bioanodes. The FAD$\mathrm{GDH} / \mathrm{P}_{2} \mathrm{Mo}_{18} / \mathrm{PMA} / \mathrm{MWCNTs}$ and the $\mathrm{FAD}-\mathrm{GDH} / \mathrm{P}_{2} \mathrm{~W}_{18} / \mathrm{PMA} / \mathrm{MWCNTs}$ electrodes were investigated in a $5 \mathrm{mmolL}^{-1}$ glucose solution for the duration of each test. Figure 5 shows the results of each stability test performed during one month. The bioelectrocatalytic currents were recorded almost every day at 0.2 V vs SCE after a 30 second discharge. Measurements were performed after 30 seconds to allow the current to stabilize and to eliminate the capacitive current of the MWCNT electrodes. Following a 45\% loss of the initial current density after the first two weeks, the FAD-GDH/ $\mathrm{P}_{2} \mathrm{Mo}_{18} / \mathrm{PMA} / \mathrm{MWCNTs}$ electrode performance decreased more gradually. A catalytic current density of $0.68 \mathrm{~mA} \mathrm{~cm}^{-2}$ was still observed after a total of 32 days (ca. 30\% of the initial current). For comparison, we recently reported a quinone-based FAD-GDH-modified MWCNT bioanode which showed high catalytic current densities for glucose oxidation but poor stability with only $48 \%$ of the initial current remaining after 5 days or ca. $20 \%$ after 9 days (Gross et al. 2017). Similar storage stability for an FADGDH electrode has been observed using an Os polymer mediator with $56 \%$ of the initial current observed after 6 days (Zafar et al. 2012). The dramatic improvement in stability for the POM electrodes, compared to the quinone and osmium-based examples from the literature, may be attributed to better physical entrapment of the mediator and enzyme in the electrode matrix. The positively-charged pyrrolidinium and pyridine cations of the POMs may also contribute to improved stabilization of the enzyme via electrostatic interactions. The steady loss of catalytic performance for the $\mathrm{P}_{2} \mathrm{Mo}_{18}$ electrode can be related to various reasons. For example, the pyrene-contain- 
ing PMA molecule, the POM, or the FAD-GDH enzyme can desorb, and/or the enzyme can lose its catalytic activity due to denaturation and inhibition. Also, the steadily decreasing $\mathrm{pH}$, resulting from the enzymatic production and accumulation of gluconic acid, may shift the redox system (I) of $\mathrm{P}_{2} \mathrm{Mo}_{18}$ to potentials where efficient electron mediation. Increased acidity may also be responsible for deactivation of FAD-GDH. For the FAD-GDH/ $\mathrm{P}_{2} \mathrm{~W}_{18} / \mathrm{PMA} / \mathrm{MWCNTs}$ electrode, due to the initial low catalytic current, the performance decrease appears more gradual up until no bioelectrocatalytic current could be measured after 25 days. The same arguments as those given for the $\mathrm{P}_{2} \mathrm{Mo}_{18}$ electrode can be taken to explain this performance loss.

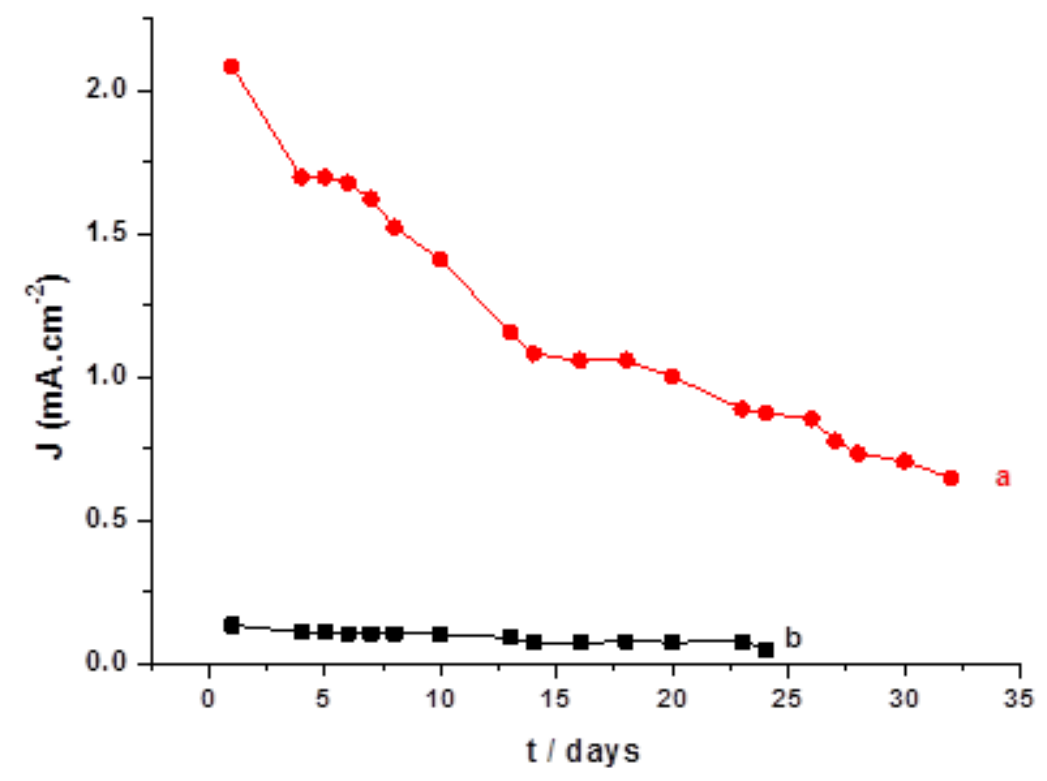

Figure 5. Stability of (a, red) FAD-GDH $/ \mathrm{P}_{2} \mathrm{Mo}_{18} / \mathrm{PMA} / \mathrm{MWCNTs}$ and (b, black) FAD$\mathrm{GDH} / \mathrm{P}_{2} \mathrm{~W}_{18} / \mathrm{PMA} / \mathrm{MWCNTs}$ electrodes. Catalytic current densities were measured by chronoamperometry at $0.2 \mathrm{~V}$ vs SCE after $30 \mathrm{~s}$ discharge in McIlvaine buffer at $\mathrm{pH} 7.0$ in the presence of $5 \mathrm{mmolL}^{-1}$ glucose.

\section{Conclusions}

$\left(\mathrm{C}_{4} \mathrm{H}_{10} \mathrm{~N}\right)_{6}\left[\mathrm{P}_{2} \mathrm{Mo}_{18} \mathrm{O}_{62}\right] \cdot 4 \mathrm{H}_{2} \mathrm{O}$ was evaluated as an electron shuttle for the electrical wiring and regeneration of FAD-dependent GDH, and revealed excellent bioelectrocatalytic performance in terms of catalytic 
current density, low onset potential and 1 month stability. This POM was compared under identical conditions with a second type of POM, $\left(\mathrm{C}_{6} \mathrm{H}_{8} \mathrm{NO}\right)_{4}\left[\mathrm{H}_{2} \mathrm{P}_{2} \mathrm{~W}_{18} \mathrm{O}_{62}\right] \cdot 6 \mathrm{H}_{2} \mathrm{O}$, for construction of bioanodes, for biofuel cell applications, or bioelectrodes for glucose biosensors. At this stage of investigation, the tungsten-based POM seems to have similar wiring capacities for FAD-GDH wiring but appeared less performing compared to the molybdenum-based POM due to immobilization issues, leading to reduced quantities by a factor 10 . To our knowledge, this is the first example of using a polyoxometalate as a redox mediator for electron transfer between an oxidoreductase enzyme and an electrode material. The excellent bioelectrocatalytic current densities on the order of several mA's and the long term stability of these glucosemediating electrodes make these organic-inorganic hybrid materials very promising candidates for glucose biofuel cell and biosensor applications. The possibility of fine tuning the redox potentials, and the enhanced long term stabilities, combine the beneficial properties of commonly used inorganic (e.g. Os complexes (refs)) and organic (e.g. quinones) (Gross et al. 2017; Milton et al. 2015) mediators. The structural and electronic versatility of POMs, including their redox properties, size and charges, promise to enable improved electrical wiring of a wide range of enzyme-electrode interfaces.

Supplementary material: All methods, chemicals, materials, and the synthesis and characterization of the POM compounds, can be found in the supplementary material document.

\section{Acknowledgment}

We gratefully acknowledge funding from the Agence Nationale de la Recherche with the project CAROUCELL (ANR-13-BIOME-0003-02). The authors wish also to acknowledge support from LabEx ARCANE (ANR-11-LABX-0003-01), the PHC Utique program n 14G1206 (CMCU), $\mathrm{n}^{\circ}$ 30583QD (Campus France), the Institute Carnot PolyNat in Grenoble, the ANR project Mocca Cell (ANR-15-JTIC0002-01), all for financial support, and the ICMG Chemistry Nanobio Platform, Grenoble, for providing facilities (PCN-ICMG). 


\section{References}

Ammam, M., 2013. J. Mater. Chem. A 1(21), 6291-6312.

Ammam, M., Easton, E.B., 2011. Electrochimica Acta 56(7), 2847-2855.

Ammam, M., Easton, E.B., 2013. J Solid State Electrochem 17(1), 137-143.

Bankar, S.B., Bule, M.V., Singhal, R.S., Ananthanarayan, L., 2009. Biotechnol. Adv. 27(4), 489-501.

Ferri, S., Kojima, K., Sode, K., 2011. J Diabetes Sci Technol. 5(5), 1068-1076.

Freire, C., Fernandes, D.M., Nunes, M., Araújo, M., 2016. Polyoxometalate-based Modified Electrodes for Electrocatalysis: From Molecule Sensing to Renewable Energy-related Applications. In: Tiwari, A., Kuralay, F., Uzun, L. (Eds.), Advanced Electrode Materials, pp. 147-212. John Wiley \& Sons, Inc., Weinheim.

Gregg, B.A., Heller, A., 1991. J. Phys. Chem. 95(15), 5976-5980.

Gross, A.J., Chen, X., Giroud, F., Abreu, C., Le Goff, A., Holzinger, M., Cosnier, S., 2017. ACS Catalysis 7, 4408-4416.

Hamidi, H., Shams, E., Yadollahi, B., Esfahani, F.K., 2008. Talanta 74(4), 909-914.

Heller, A., 1992. J. Phys. Chem. 96(9), 3579-3587.

Hmida, F., Ayed, M., Ayed, B., Haddad, A., 2015. J. Chem. Sci. 127(9), 1645-1651.

Ji, Y., Huang, L., Hu, J., Streb, C., Song, Y.-F., 2015. Energy Environ. Sci. 8(3), 776-789.

Keita, B., Nadjo, L., 1987. J Electroanal Chem Interfacial Electrochem 227(1), 77-98.

Long, D.-L., Burkholder, E., Cronin, L., 2007. Chem. Soc. Rev. 36(1), 105-121.

Mano, N., Mao, F., Heller, A., 2002. J. Am. Chem. Soc. 124(44), 12962-12963.

Marcus, R.A., Sutin, N., 1985. Biochimica et Biophysica Acta (BBA) - Reviews on Bioenergetics 811(3), 265-322.

Milton, R.D., Hickey, D.P., Abdellaoui, S., Lim, K., Wu, F., Tan, B., Minteer, S.D., 2015. Chem. Sci. $6(8), 4867-4875$.

Miras, H.N., Yan, J., Long, D.-L., Cronin, L., 2012. Chem. Soc. Rev. 41(22), 7403-7430.

Pinyou, P., Ruff, A., Pöller, S., Ma, S., Ludwig, R., Schuhmann, W., 2016. Chem. Eur. J. 22(15), 53195326. 
Reuillard, B., Abreu, C., Lalaoui, N., Le Goff, A., Holzinger, M., Ondel, O., Buret, F., Cosnier, S., 2015. Bioelectrochem. 106(Part A), 73-76.

Saboe, P.O., Conte, E., Farell, M., Bazan, G.C., Kumar, M., 2017. Energy Environ. Sci. 10(1), 14-42.

Sadakane, M., Steckhan, E., 1998. Chem. Rev. 98(1), 219-238.

Sahraoui, Y., Chaalia, S., Maaref, A., Haddad, A., Bessueille, F., Jaffrezic-Renault, N., 2016. Electroanal. Chem. 781, 190-197.

Saleem, M., Yu, H., Wang, L., Zain ul, A., Khalid, H., Akram, M., Abbasi, N.M., Huang, J., 2015. Anal. Chim. Acta. 876, 9-25.

Turdean, G.L., Curulli, A., Catalin Popescu, I., Rosu, C., Palleschi, G., 2002. Electroanalysis 14(22), $1550-1556$.

Ueda, T., 2015. Review of Polarography 61(1), 11-19.

Wang, C.-T., Hua, Y.-J., Sun, Z.-F., Wei, J.-C., Li, T.-L., Tong, Y.-X., Liu, X.-Y., 2011. Acta Phys Chim Sin 27(2), 473-478.

Wang, J., 2002. Sensors Update 10(1), 107-119.

Wang, X., Chang, Z., Lin, H., Xu, C., Luan, J., Liu, G., Tian, A., 2015. RSC Advances 5(45), 3553535540 .

Wilson, R., Turner, A.P.F., 1992. Biosens. Bioelectron. 7(3), 165-185.

Zafar, M.N., Beden, N., Leech, D., Sygmund, C., Ludwig, R., Gorton, L., 2012. Anal.Bioanal. Chem. 402(6), 2069-2077.

Zhang, W., Du, D., Gunaratne, D., Colby, R., Lin, Y., Laskin, J., 2014. Electroanalysis 26(1), 178-183.

Zhao, M., Gao, Y., Sun, J., Gao, F., 2015. Anal. Chem. 87(5), 2615-2622.

Zhou, C., Li, S., Zhu, W., Pang, H., Ma, H., 2013. Electrochim. Acta 113, 454-463.

Zhou, M., Guo, L.-p., Lin, F.-y., Liu, H.-x., 2007. Anal. Chim. Acta 587(1), 124-131. 